\title{
Krzysztof BIERNAT
}

Instytut Ekologii i Bioetyki, UKSW, Warszawa

\section{Paulina Luiza DZIOŁAK}

Instytut Ekologii i Bioetyki, UKSW, Warszawa

\section{Izabela SAMSON-BRECK}

Instytut Ekologii i Bioetyki, UKSW, Warszawa

\section{Stan i prognoza rozwoju systemu gospodarki odpadami w Europie i USA}

Słowa kluczowe: odpady, recykling, unieszkodliwianie, energia

Key Word: wastes, recycling, waste treatment, energy

\section{Wprowadzenie}

Rozwój cywilizacji powoduje znaczny wzrost ilości produkowanych odpadów, co stanowi istotny problem zarówno krajów uprzemysłowionych jak i krajów rozwijających się. Poza odpadami przemysłowymi powstają również odpady komunalne, które produkowane są w dużych ilościach, zwłaszcza w dużych aglomeracjach miejskich.

Zarówno odpady przemysłowe jak i komunalne mają znaczny wpływ na zanieczyszczenie środowiska przyrodniczego. Powodują one straty gospodarcze i społeczne, które określane są mianem strat ekologicznych. Rozwój gospodarczy kraju musi być zgodny z wymaganiami ochrony środowiska.

Odpady stanowią również potencjalny surowiec energetyczny, z którego $\mathrm{z}$ powodzeniem można pozyskiwać energię cieplną lub energię elektryczną w sposób ekologicznie opłacalny (Czajka et al. 2000: 1).

Przyjmuje się, że aż około 40\% energii przetwarzane jest w sposób pośredni lub bezpośredni na produkcję odpadów m.in. poprzez pro- 
dukcję zbędnych w wielu przypadkach opakowań, a także wielojęzycznych instrukcji obsługi.

Ponadto szacuje się, że około $1 / 3$ przetwarzanej energii jest zużywana na pokonywanie oporów tarcia, w efekcie czego powstaje ciepło, tzw. ciepło odpadowe.

Wskutek tego tylko 30-35\% energii jest wykorzystywana w zamierzonym celu, a to implikuje podjęcie prac nad możliwościami wysoko efektywnych rozwiązań odzysku energii, między innymi odzysku energii z odpadów poprzez ich odpowiednie przetworzenie. Odzysk energii z substancji odpadowych określany jest obecnie mianem procesów WtE (Waste to Energy).

\section{Energetyczne wykorzystanie odpadów na Świecie}

$\mathrm{Na}$ całym świecie około $130 \mathrm{mln}$ Mg odpadów komunalnych jest rocznie spalanych w ponad 600 instalacjach WtE (waste to energy), które zarówno produkują energię elektryczną i cieplną, jak i też odzyskują metale w procesach recyklingu. W latach 1995-2003 globalny przemysł WtE rozwinął swoje możliwości przerobowe o $16 \mathrm{mln} \mathrm{Mg}$ odpadów komunalnych rocznie. W roku 2003 instalacje WtE istniały w 35 krajach, a większość z najnowszych instalacji tego typu powstała w Azji (Themelis 2003: 40-41).

Przegląd europejskiego przemysłu WtE sporządzony w 2002 roku przez Międzynarodowe Stowarzyszenie Odpadów Stałych pokazuje, że całkowita zdolność produkcyjna istniejących instalacji była większa niż $40 \mathrm{mln} \mathrm{Mg/rok,} \mathrm{a} \mathrm{produkcja} \mathrm{energii} \mathrm{elektrycznej} \mathrm{i} \mathrm{cieplnej} \mathrm{wyno-}$ siła odpowiednio $41 \mathrm{mln}$ GJ i $110 \mathrm{mln}$ GJ. Dobrym przykładem instalacji kogeneracyjnej jest placówka WtE w Brecia we Włoszech, która produkuje około $650 \mathrm{kWh}$ energii elektrycznej na Mg spalonych odpadów. W zimie instalacja ta zapewnia przynajmniej tyle energii, ile jej potrzeba na cele grzewcze (Themelis 2003: 41-42).

Według danych Eurostatu z 2007 roku w krajach europejskich (EU 27) postępowanie $\mathrm{z}$ odpadami przedstawia się w sposób następujący. 

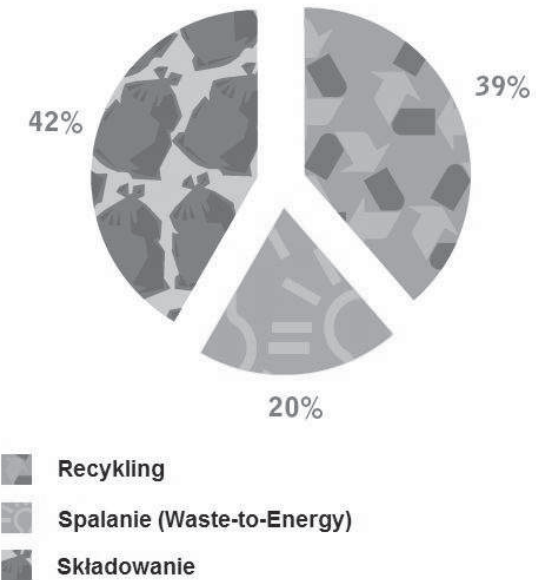

Rys. 1. Postępowanie z odpadami w krajach europejskich (EU 27) w 2007 roku (Brochure of CEWEP 2009: 5)

Jak wynika z rys. 1, ponad $40 \%$ odpadów składowanych jest na wysypiskach, około $39 \%$ odpadów poddawanych jest procesom recyklingu, a jedynie $20 \%$ odpadów poddawanych jest procesom spalania wraz $\mathrm{z}$ odzyskiem energii.

Pomimo tego, z odpadów pozostałych, które nie mogą być ponownie wykorzystane, ani poddane recyklingowi w technicznie lub ekonomicznie opłacalny sposób, energia powinna być nich wytwarzana i powinno to stanowić jasny priorytet przewyższający procesy składowania odpadów. Kraje przodujące w dziedzinie gospodarowania odpadami, które zdecydowanie ograniczyły składowanie odpadów na terenie swojego państwa, dokonały tego poprzez połączenie procesów recyklingu, przetwarzania za pomocą metod biologicznych (np. kompostowania lub fermentacji beztlenowej) oraz procesów przetwarzania odpadów z odzyskiem energii (Waste-to-Energy).

Ze względu na wzrost ilości instalacji WtE w Europie, od 2005 roku zaobserwowano największy wzrost energii produkowanej z odpadów w Niemczech, Holandii i Szwecji - krajach, przodujących w zakre- 
sie ochrony środowiska, i które ograniczyły składowanie odpadów do mniej niż 4\% (Brochure of CEWEP 2009: 5-7).

Na rys. 2, przedstawiono proponowaną hierarchię metod postępowania z odpadami, sporządzoną i proponowaną przez Konfederację Europejskich Instalacji Waste-to-Energy.

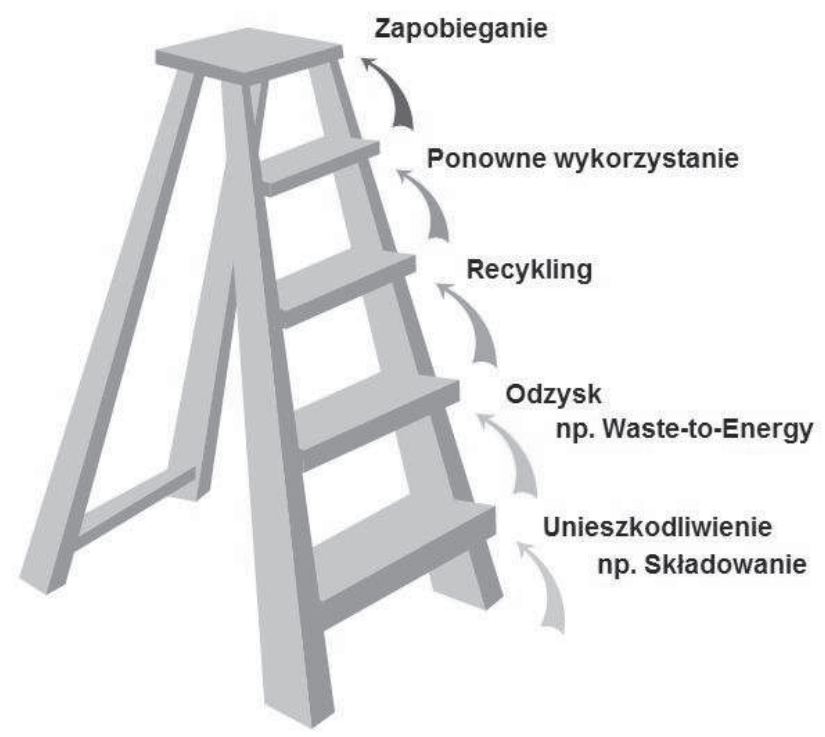

Rys. 2. Ogólna hierarchia metod postępowania z odpadami, (Brochure CEWEP 2009, 7)

$\mathrm{Z}$ rys. 2 wynika, że postępowanie $\mathrm{z}$ odpadami to nie tylko recykling, spalanie czy składowanie, ale również formy prewencji, czyli zapobiegania powstawaniu odpadów, a także możliwość ponownego ich wykorzystania. Na szczycie „drabiny hierarchii” stoi więc zapobieganie powstawaniu odpadów, co jest swoistym działaniem „u źródła”. Unieszkodliwianie odpadów w postaci ich składowania leży najniżej w hierarchii i traktowane jest jako ostateczność.

Przykładowo, jeżeli około 65 mln Mg odpadów komunalnych zostałoby poddanych procesom WtE, wówczas ilość otrzymanej energii elektrycznej wynosiłaby około 28 mld kWh, co umożliwiłoby zaopatrzenie 
w prąd elektryczny $12 \mathrm{mln}$ osób. Ta sama ilość odpadów poddana procesom WtE spowodowałaby wytworzenie 65 mld kWh energii cieplnej, co wystarczyłoby na zaopatrzenie w ciepło $11 \mathrm{mln}$ osób. Jednocześnie oszacować można, że wykorzystanie w sposób energetyczny takiej ilość odpadów komunalnych powoduje oszczędność paliw konwencjonalnych takich jak ropa naftowa czy węgiel kamienny w ilości około 6-35 mln Mg tych paliw (Brochure CEWEP 2009: 19).

Amerykański przemysł WtE obejmuje około 23\% instalacji w świecie, a $\mathrm{z}$ tego 66\% rynku WtE w zlokalizowane jest na wschodnim wybrzeżu USA. Stany Zjednoczone potroiły ilość wytwarzanych odpadów w stosunku do roku 1960. Podczas gdy w roku 1960 ilość wytwarzanych odpadów wynosiła około $85 \mathrm{mln}$ Mg, w 2005 roku ilość ta wzrosła do $245 \mathrm{mln} \mathrm{Mg.} \mathrm{W} 2003$ roku w USA istniało około 102 spalarni z możliwością odzysku energii, oparte na technologiach WtE. Udział odpadów spalanych w licznych instalacjach kotłowych zwiększył się z 9\% w 1980 roku do 14\% w 2002 roku (dla porównania, w analogicznym czasie ilość odpadów poddawanych recyklingowi wzrosła z 10\% do $28 \%$ ). W chwili obecnej najbardziej popularnym sposobem postępowania z odpadami jest ich składowanie, które dotyczy ponad 50\% odpadów wytwarzanych w tym kraju. Około 32\% odpadów poddawanych jest procesom kompostowania lub recyklingowi, a jedynie 13,6\% wykorzystywanych jest na cele grzewcze. W Stanach Zjednoczonych z odpadów wytwarzanych rocznie w ilości blisko ćwierć miliarda $\mathrm{Mg}$ spala się około $30 \mathrm{mln} \mathrm{Mg}$, uzyskując z nich moc elektryczną $2800 \mathrm{MW}$. Segregacja odpadów prowadzona w amerykańskich spalarniach umożliwia rocznie odzysk około $773.000 \mathrm{Mg}$ złomu stalowego, 460.000 Mg innych metali, szkła, tworzyw sztucznych, itd. Innowacyjne technologie powodują zmniejszenie masy składowanych odpadów komunalnych o 90\%. Reszta - w postaci szklistych pozostałości - zostaje zużyta jako materiał do budowy dróg lub rekultywacji wysypisk śmieci w sposób skutecznie zabezpieczający je przed wypłukiwaniem i wydzielaniem szkodliwych związków (Swedish Trade Council 2008: 15-25).

Instalacje WtE w USA nie są zwykle wykorzystywane na cele grzewcze. Większość z nich produkuje jedynie energię elektryczną. 
Ilość odpadów komunalnych wykorzystywanych w celu odzysku energii wykładniczo wzrosła po 1980 roku z poziomu około $2,5 \mathrm{mln}$ $\mathrm{Mg}$ do $30 \mathrm{mln} \mathrm{Mg}$ rocznie w roku 1990. Po tym roku nie zaobserwowano już wzrostu wykorzystywania procesów spalania odpadów połączonych z odzyskiem energii. Głównym powodem tak silnego wzrostu odzysku energii z odpadów komunalnych w latach 1980-1990 była potrzeba znalezienia pro środowiskowych alternatywy dla nieuregulowanych otwartych wysypisk oraz konieczność rozwoju alternatywnych źródeł energii w celu ograniczenia uzależnienia od ropy naftowej (Swedish Trade Council 2008: 15-25).

Pomimo tego, że ostatnie dwie dekady były w USA trudne dla przemysłu WtE, istnieją przesłanki do tego, że należy ten rynek wciąż rozwijać i powiększać. Rosnące ceny energii elektrycznej powodują, że produkcja WtE staje się bardziej opłacalna, a wyższe ceny paliwa podwyższają koszty transportu odpadów na wysypiska. Istnieje wiele regionalnych zachęt i zarządzeń, które wspierają rozwój instalacji WtE w USA.

\section{Energetyczne wykorzystanie odpadów w Niemczech}

Niemcy postrzegane są jako kraj wysoko rozwinięty, wykorzystujący najnowsze technologie. To również kraj, który dynamicznie rozwija się pod kątem ochrony środowiska. Może poszczycić się niemalże największym zagęszczeniem instalacji do energetycznego przetwarzania odpadów.

Na rys. 3 przedstawiono modele zarządzania odpadami miejskimi w Niemczech i innych krajach europejskich.

Jak widać na rys. 3 Niemcy przodują w zakresie gospodarowania odpadami wśród krajów europejskich. Aż około $48 \%$ odpadów poddawanych jest tu procesom recyklingu, 35\% ulega procesom spalania $\mathrm{z}$ odzyskiem energii, a $17 \%$ poddawane jest procesowi kompostowania. Proste składowanie odpadów w Niemczech nie występuje. 


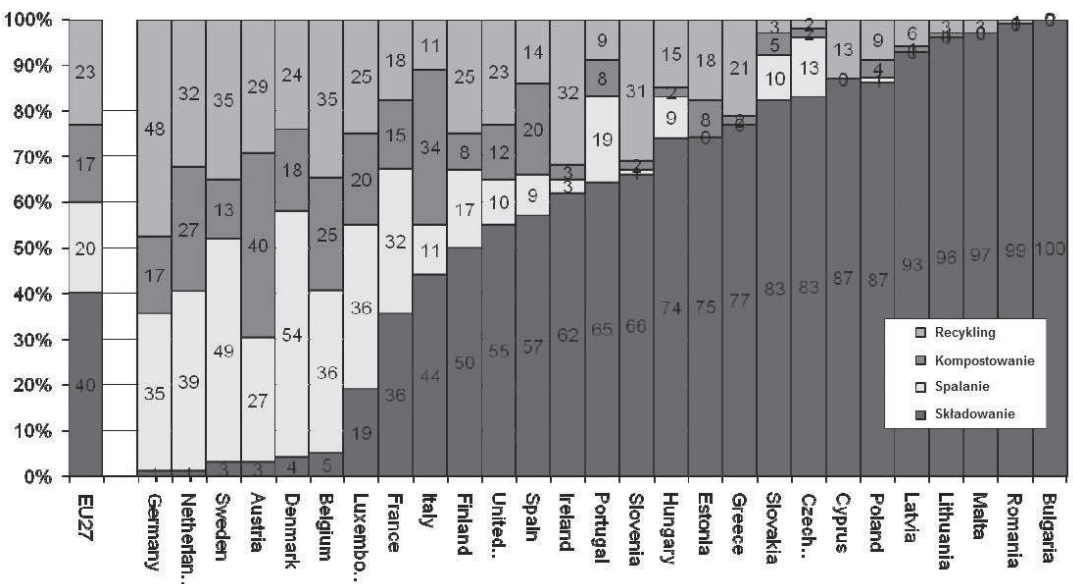

Rys. 3. Zarządzanie odpadami miejskimi w krajach UE (2008)

(Spohn 2010a: 43)

W Niemczech rocznie wytwarza się około $340 \mathrm{mln} \mathrm{Mg}$ odpadów. Około $48 \mathrm{mln} \mathrm{Mg}$ odpadów stanowią odpady komunalne, z których $23 \mathrm{mln} \mathrm{Mg}$ są poddawane recyklingowi, a $25 \mathrm{mln} \mathrm{Mg}$ poddawanych jest procesom odzysku energii (Spohn 2010b: 1).

Strategia podstępowania $\mathrm{z}$ odpadami w Niemczech jest następująca:

- segregacja odpadów;

- produkcja „odzyskanych” surowców, takich jak szkło, papier, tworzywa sztuczne, metale itd.;

- nieprzetworzone odpady komunalne, zebrane ze składowisk od 2005 roku;

- odzysk energii z pozostałych odpadów;

- produkcja odpadowych paliw transportowych (RFD - Refuse Derived Fuels) i odzyskanych paliw (SRF - Secondary Recovered Fuels).

$\mathrm{W}$ Niemczech istnieje 50 instalacji $\mathrm{WtE}$ produkujących energię w kogeneracji (ciepło i energię elektryczną), 10 instalacji WtE produkujących tylko energię elektryczną oraz 8 instalacji WtE produkujących tylko ciepło lub parę procesową. Całkowita moc przerobowa instalacji WtE spalających odpady komunalne to około 20,2 mln Mg/rok, około 
$5 \mathrm{mln} \mathrm{Mg}$ dla instalacji produkujących odpadowe paliwa transportowe (RFD) oraz około $2 \mathrm{mln} \mathrm{Mg}$ dla instalacji współspalania odpadów (Spohn 2010b: 1-4).

Na rys. 4 przedstawiono rozwój instalacji WtE w Niemczech na przestrzeni lat 1965 i 2008, z uwzględnieniem liczby instalacji oraz ich sumarycznej mocy przerobowej.

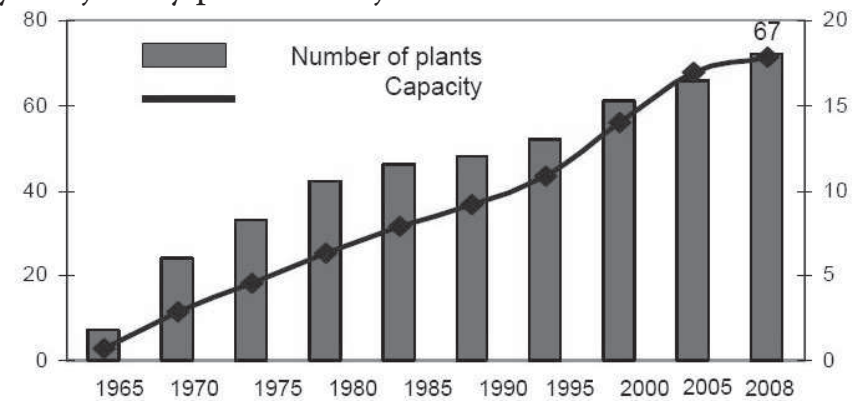

Rys. 4. Liczba instalacji WtE w Niemczech w latach 1965-2008 wraz z sumaryczną mocą przerobową (Spohn 2010a: 6)

Tak intensywny rozwój przemysłu WtE został podyktowany przesłankami, takimi jak zredukowanie ilości powstających odpadów, minimalizacja emisji, efektywne wykorzystanie energii zgromadzonej w odpadach, a także ochrona klimatu.

W Niemczech najczęściej odzyskuje się energię z odpadów biogennych, odpadów komunalnych i podobnych odpadów komercyjnych.

$\mathrm{W}$ tabeli 1 przedstawiono moc niemieckich instalacji WtE oraz produkcję energii na przestrzeni lat 2005-2008.

\begin{tabular}{|l|c|c|c|c|c|}
\hline Wartość & $\mathbf{2 0 0 5}$ & $\mathbf{2 0 0 6}$ & $\mathbf{2 0 0 7}$ & $\mathbf{2 0 0 8}$ & $\begin{array}{c}\text { zmiana } \\
\mathbf{2 0 0 5} \text { to } \mathbf{2 0 0 8}\end{array}$ \\
\hline $\begin{array}{l}\text { Energia cieplna } \\
\text { exp. (min MWh) }\end{array}$ & 13.19 & 13.72 & 13.75 & 14.44 & $+9.5 \%$ \\
\hline Moc (MW) & 1210 & 1250 & 1330 & 1440 & $+19.0 \%$ \\
\hline $\begin{array}{l}\text { Energia elektryczna } \\
\text { produkowana (mln MWh) }\end{array}$ & 5.51 & 6.26 & 6.93 & 7.35 & $+33.3 \%$ \\
\hline $\begin{array}{l}\text { Energia elektryczna } \\
\text { exp. (min MWh) }\end{array}$ & 3.95 & 4.54 & 5.16 & 5.50 & $+39.1 \%$ \\
\hline
\end{tabular}

Tabela 1. Moc instalacji WtE oraz produkcja energii elektrycznej i cieplnej w Niemczech w latach 2005-2008 (Spohn 2010a: 28) 
Z tabeli 1 wynika, że zarówno produkcja energii z odpadów jak i moce wytwórcze rosną wraz z upływem czasu. Ilość energii elektrycznej produkowanej z odpadów wzrosła o 33,3\%, moce wytwórcze natomiast wzrosły o $19,0 \%$.

$\mathrm{Na}$ rys. 5 przedstawiono efektywność energetyczną istniejących instalacji WtE w Niemczech.

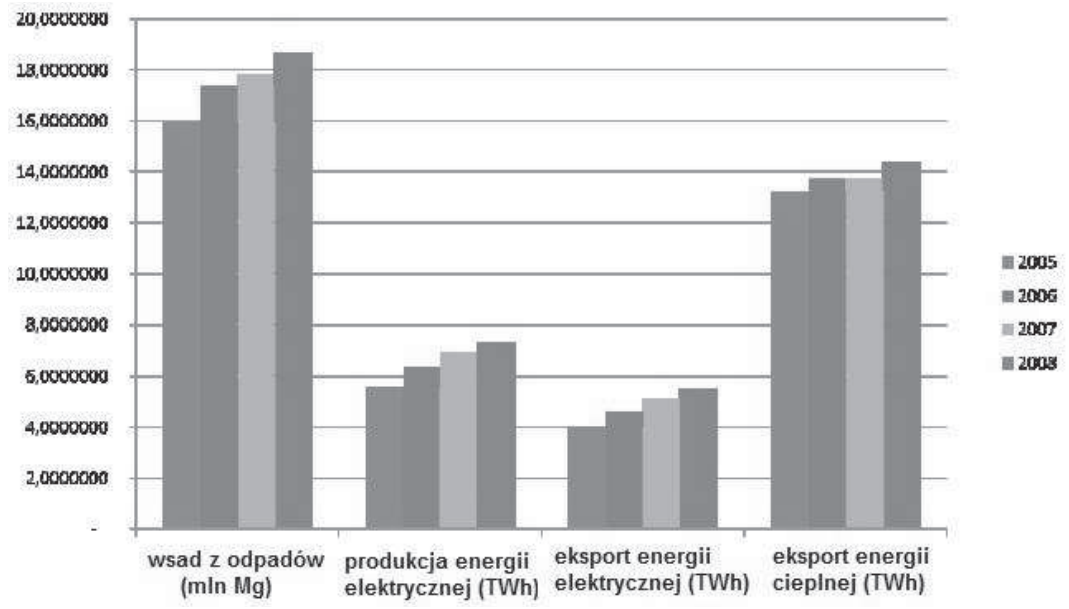

Rys. 5. Efektywność energetyczna instalacji WtE w Niemczech (Spohn 2010a: 29)

Jak wynika z rysunku coraz więcej odpadów jest w Niemczech przetwarzanych z odzyskiem energii. W 2005 roku przetwarzano około $16 \mathrm{mln} \mathrm{Mg}$ odpadów, natomiast już w 2008 roku przetwarzano niemalże $19 \mathrm{mln} \mathrm{Mg.} \mathrm{Rośnie} \mathrm{również} \mathrm{poziom} \mathrm{pozyskiwanej} \mathrm{energii} \mathrm{z} \mathrm{od-}$ padów, np. w 2005 roku produkcja energii elektrycznej z odpadów wynosiła około 4,8 TWh natomiast już w 2008 produkcja ta wynosiła ponad 7 TWh w skali roku i wciąż rośnie.

$\mathrm{Na}$ fotografii (rys. 6) pokazano widok przykładowej instalacji WtE (instalacja TAD) w Niemczech w mieście Ulm. 


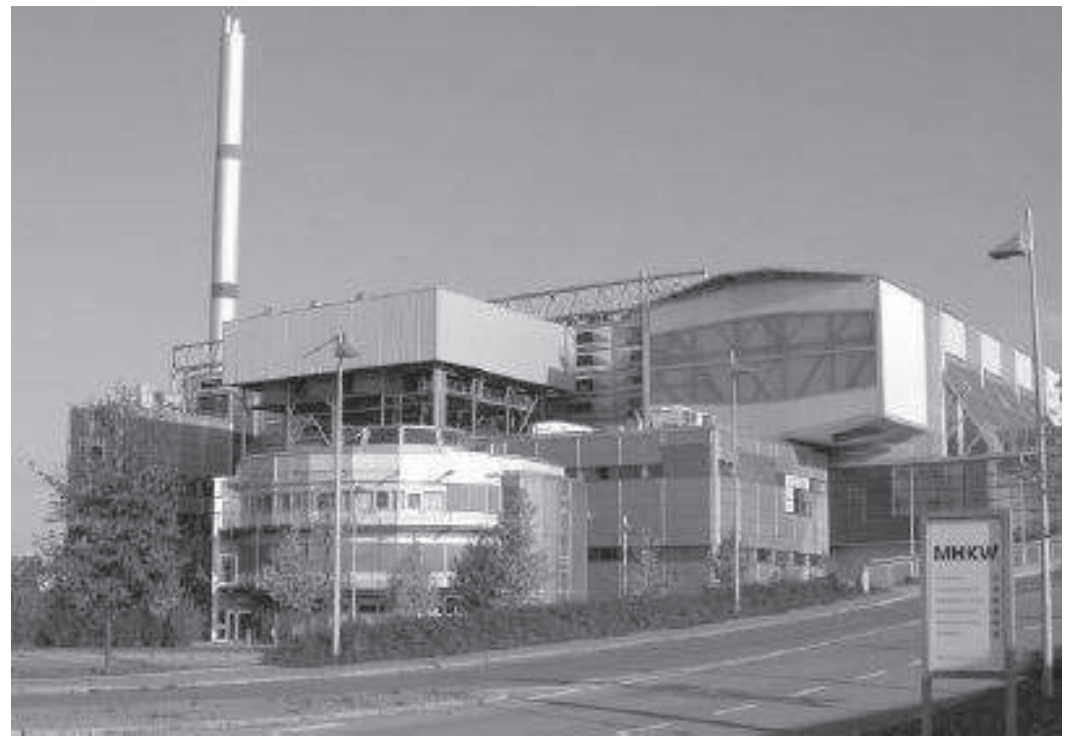

Rys. 6. Instalacja WtE TAD Ulm, Niemcy (Spohn 2010a: 39)

Instalacja TAD Ulm, jest dwuliniowa, a jej całkowita moc przerobowa to około $15000 \mathrm{Mg} /$ rok, przy produkcji energii około $40000 \mathrm{MWh}$ / rok. Miasto Ulm w 45\%-ach jest zaopatrywane w energię cieplną przez instalację WtE. Energia dostarczana jest poprzez zintegrowaną sieć energetyczną (Spohn 2010a: 39-40).

\section{Energetyczne wykorzystywanie odpadów w Holandii}

Holandia cieszy się reputacją kraju progresywnego, poczynając od dziedziny ochrony środowiska po inicjatywy społeczne. Holandia jest jednocześnie uznawana jako centrum kreatywności, efektywności i różnorodności. Jest także pionierem w kreowaniu podejścia do gospodarki odpadami i rekultywacji wód.

Już w 2004 roku w Holandii jedynie około 3-4\% odpadów była składowana na wysypiskach, natomiast 35\% poddawało się procesom spa- 
lania z odzyskiem energii, a 53\% poddawano recyklingowi (den Herder 2007: 3).

W Holandii gospodarka odpadami jest realizowana w oparciu o następujące cele podstawowe:

- zapobieganie nadmiernemu powstawaniu odpadów,

- ograniczanie ilości odpadów składowanych na wysypiskach,

- kompostowanie odpadów organicznych,

- odzysk energii z odpadów (procesy WtE),

- wdrażanie metod efektywnego recyklingu surowcowego i materiałowego.

W wyniku osiągnięcia tych celów możliwe będzie znaczne zredukowanie emisji gazów cieplarnianych, zmniejszenie zapotrzebowania na źródła energii (inne niż odpady), a także powstanie wielu nowych miejsc pracy.

Na rys. 3 przedstawiono modele zarządzania odpadami miejskimi Holandii i innych krajach europejskich. Podobnie jak Niemcy, Holandia również przoduje w dziedzinie gospodarowania odpadami. Około 39\% odpadów ulega tam procesom spalania, 32\% podlega procesom recyklingu, a 27\% odpadów jest kompostowanych. Składowanie nie ma miejsca w Holandii (Spohn 2010a: 43).

Na przestrzeni ostatniego dwudziestolecia odpady w Holandii w dużej mierze zaczęły być poddawane procesom kompostowania, jak to pokazano na rys. 7 .

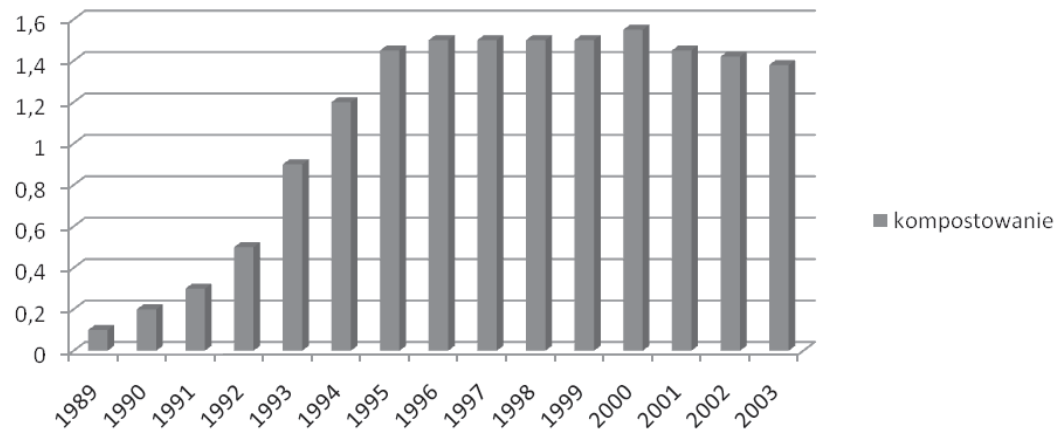

Rys. 7. Ilość odpadów poddawanych procesom kompostowania w gospodarce odpadami w Holandii w latach 1989-2003 (w mln Mg) (den Herder 2007: 8) 
Jednocześnie zaobserwowano systematyczną tendencję redukcyjną powierzchni i ilości składowisk odpadów w Holandii na przestrzeni lat 1993-2003. Zmiany te ilustruje rys. 8.

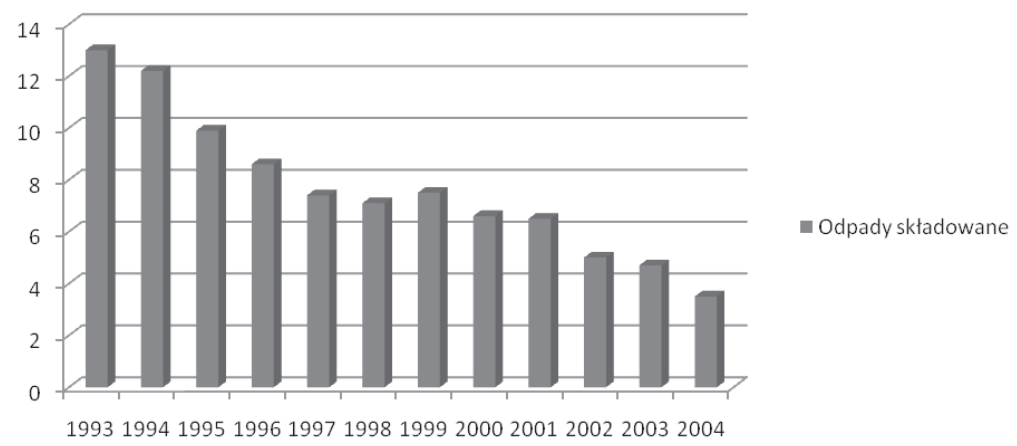

Rys. 8. Ilość odpadów składowanych na wysypiskach w Holandii w latach 1993-2004 (w mln Mg) (den Herder 2007: 9)

Jak widać na rys. 8, w stosunku do roku bazowego 1993 ilość składowisk odpadów, w przeliczeniu na wagę składowanych odpadów, zmniejszyła się do roku 2004, o 75\% i wciąż malała, by w 2008 roku problem składowania odpadów w Holandii zniknął zupełnie.

System gospodarowania odpadami w Holandii jest złożony. Wynika to przede wszystkim z braku obszarów dostępnych na składowiska więc odpady komunalne są spalane z odzyskiem energii lub wywożone poza kraj celem usunięcia.

W Amsterdamie uruchomiono instalację WtE - spalarnię odpadów komunalnych - Afval Energie Bedrijf (AEB), która może produkować $1 \mathrm{mln}$ MWh energii elektrycznej rocznie. Poza energią elektryczną, instalacja również jest wykorzystywana do wytwarzania 300000 GJ ciepła rocznie (Web-01) dla celów komunalnych. Instalacja AEB jest światowym liderem $\mathrm{w}$ dziedzinie energetycznego przetwarzania odpadów przy jednoczesnym minimalnym wpływie na środowisko. Codziennie 600 samochodów ciężarowych dostarcza do instalacji $4400000 \mathrm{~kg}$ odpadów. 
Instalacja AEB wraz $\mathrm{z}$ niezależną instalacją oczyszczania wody Waternet działają symbiotycznie. Instalacja AEB dostarcza energii elektrycznej i ciepła dla procesów uzdatniania wody, natomiast instalacja Waternet przekazuje swój osad ściekowy i biogaz do spalarni jako dodatkowe źródło paliwowe.

W skali jednego roku 1,4 mln Mg odpadów dostarczanych jest do instalacji WtE (Web-01).

Poprzez uwzględnienie efektów niekorzystnych środowiskowo, powodowanych przez gazy ulatniające się w realizowanych procesach, zastosowano złożony proces oczyszczania gazów odlotowych. W skład tego systemu wchodzą: filtr służący do oddzielenia popiołów lotnych, oraz filtr tkaninowy, stosowany w celu usunięcia innych pozostałości przed przekazaniem do ekonomizera.

W następnej kolejności gazy odlotowe przechodzą przez szereg płuczek wieżowych, służących do usuwania szkodliwych gazów i pyłów. W płuczce $\mathrm{HCl}$ odzyskuje się chlorek wapnia, w płuczce $\mathrm{SO}_{2}$ - siarkę, a płuczka polerująca usuwa znaczną część pozostałej pary wodnej.

Dla wielu z produktów ubocznych powstających w procesie spalania odpadów w instalacji AEB, podejmowane są próby zamknięcia tzw. pętli w ten sposób, aby otrzymany materiał mógł być wykorzystywany w innych procesach przemysłowych - od pierwiastków śladowych do produkcji, po popioły lotne do budowy.

Gaz ostatecznie opuszczający instalację, to głównie para wodna i oczyszczony gaz odlotowy. Dioksyny z procesu spalania są wychwytywane i bezpiecznie usuwane.

Oczyszczanie gazów odlotowych z pieca instalacji pozwala na odzyskanie cennych surowców. Przykładowo odzyskana siarka jest wykorzystywana do produkcji płyt kartonowo-gipsowych dla przemysłu budowlanego, a odzyskany chlorek wapnia jest używany do odmrażania dróg w sezonie zimowym.

Nie wszystkie odpady w instalacji AEB są spalane. Pozostały na dnie popiół składa się z żużlu, granulatu, szkła i metali. Aby zmaksymalizować ilość surowców pozyskanych z odpadowego popiołu, instalacja AEB wraz z TU Delft wybudowały instalację pilotażową dla odzyskiwania metali szlachetnych. Odpady z instalacji AEB mogłyby 
być wtedy wykorzystane do produkcji granulatu i tzw. „sztucznego piasku", nadających się do wykorzystania w budownictwie. Celem dalszego udoskonalania, AEB prowadzi intensywne prace na rzecz rozwoju instalacji, która mogłaby przekształcić odpadowy popiół w produkty jeszcze wyższej jakości, takie jak surowce nadające się do produkcji betonu czy asfaltu (Web-02).

Schemat instalacji WtE - „Elektrownię opalaną odpadami” (WFPP - Waste Fired Power Plant) przedstawiono na rys. 9.

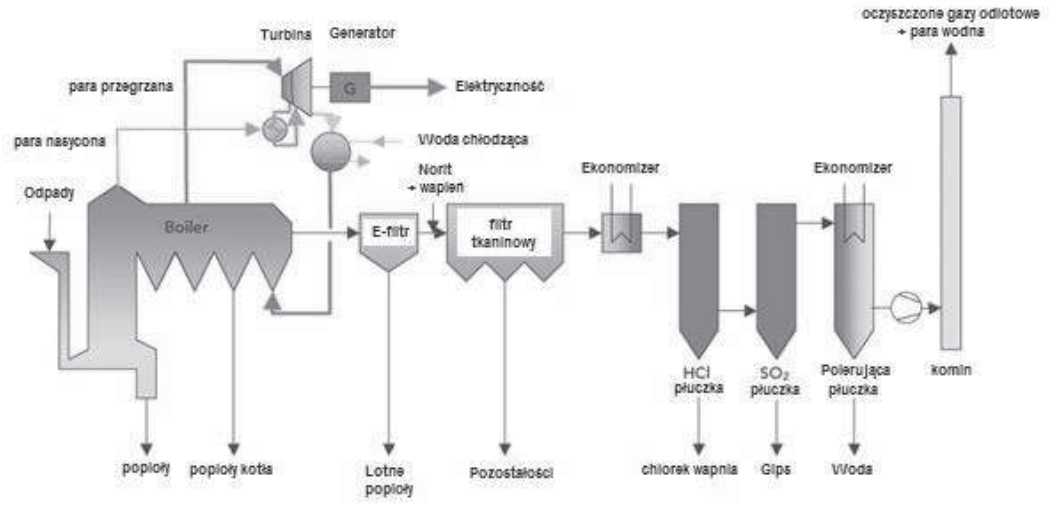

Rys. 9. WFPP - Elektrownia opalana odpadami - wysoko wydajna koncepcja odzysku energii z odpadów (Web-01)

Wdrożona technologia realizacji procesów WtE powoduje zmniejszenie emisji ditlenku węgla o 438 tys. $\mathrm{Mg} \mathrm{CO}_{2}$ rocznie przy spalaniu w instalacji $1 \mathrm{mln} \mathrm{Mg}$ odpadów (Web-01). Ze względu na połączenie procesów spalania $\mathrm{w}$ instalacji AEB z procesami oczyszczania wody w instalacji Waternet, w ogólnym rozrachunku proces znacznie zmniejsza wartość węgla usuwanego do atmosfery.

Przy rozpatrywaniu scenariusza alternatywnego, jeśli $1 \mathrm{mln} \mathrm{Mg}$ odpadów nie zostałby poddany procesom spalania, tylko zostałby umieszczony na składowiskach, wysokość ekwiwalentu $\mathrm{CO}_{2}$ rocznie wynosiłby 1036 tys. $\mathrm{Mg} \mathrm{CO}_{2}$ (rys. 10). Wielkość tego ekwiwalentu wynika m.in. z przelicznika ilości emitowanego metanu jako gazu składowiskowego. Jeżeli metan byłby wychwytywany lub składowany, to ekwiwalent $\mathrm{CO}_{2}$ 
uległby zmniejszeniu do 404 tys. Mg, co niestety wciąż stanowi dużą jego ilość (Web-01).

W zakładzie AEB uzyskany biogaz o czystości gazu ziemnego jest obecnie dostarczany do sieci przesyłowej tego gazu, a także przeznaczony do zasilania małej floty pilotażowej 120 pojazdów zasilanych biogazem. Rocznie fermentacyjna produkcja gazu w Waternet wynosi 7,5 mln $\mathrm{m}^{3}$. Ilość ta wystarcza na potrzeby 5000 gospodarstw domowych oraz 3500 samochodów (Web-01).

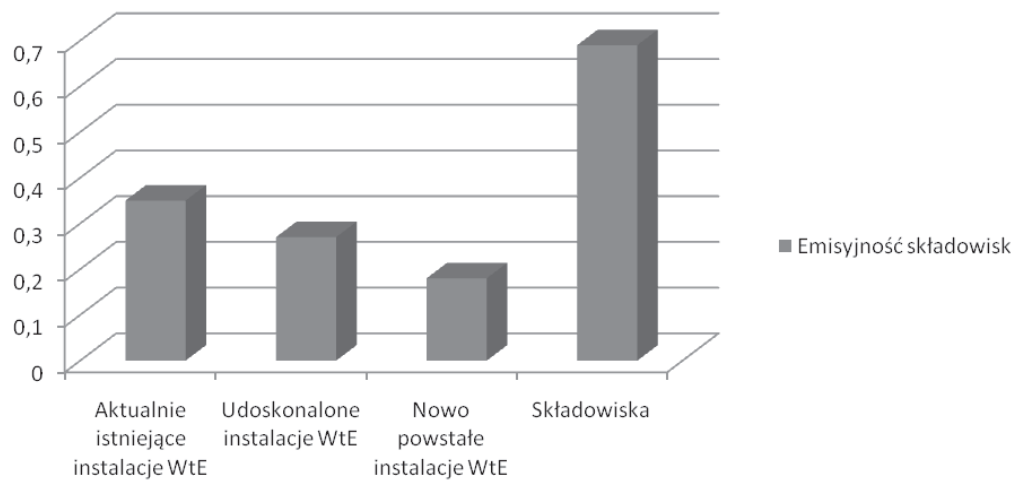

Rys. 10. Porównanie emisyjności składowiska odpadów z opcjami instalacji spalania odpadów (w stosunku tony $\mathrm{CO}_{2}$ /tony odpadów) (den Herder 2007: 20)

Podstawowym pozytywnym czynnikiem zakładów WtE jest ich efektywność. Stanowi ona o możliwościach energetycznego przetwarzania odpadów z uwzględnieniem wymagań środowiskowych. Jeżeli odpady na terenie całej Unii Europejskiej byłyby traktowane w podobny sposób, szacuje się, że instalacje WtE mogłyby wygenerować $8 \%$ łącznej produkcji energii elektrycznej w UE poprzez spalenie $182 \mathrm{mln}$ $\mathrm{Mg}$ odpadów, oraz w zapobieżenie emisji $200 \mathrm{mln} \mathrm{Mg} \mathrm{CO}$ rocznie. Jednocześnie zwolniły by się duże ilości ziemi, do tej pory używane na cele składowiskowe. 
Krzysztof Biernat, Paulina Luiza Dziołak, Izabela Samson-Bręk

\section{Energetyczne wykorzystywanie odpadów w Szwecji}

Kryzys energetyczny, który nastąpił w Szwecji w połowie lat 70-tych stanowił poważny bodziec do szukania zmian w kwestii nośników energii. W tym czasie w przeciągu kilku miesięcy dostawcy tradycyjnego paliwa pochodzącego z ropy naftowej podnieśli jego cenę kilkukrotnie. Wywołało to ogromny stres w społeczeństwie żyjącym w zimnym klimacie, o najostrzejszym prawie i nieposiadającym własnych paliw kopalnych, społeczeństwie przyzwyczajonym do najwyższej stopy życiowej na świecie i wysokiego komfortu cieplnego.

Sytuacja kryzysowa spowodowała poszukiwanie możliwości wykorzystywania niekonwencjonalnych źródeł energii, w tym różnego rodzaju odpadów. Rozpoczęto rozbudowę systemu ciepłownictwa centralnego, aby w optymalny sposób zagospodarować rozproszoną energię cieplną. Wyniknął jednak problem rentowności tych rozwiązań, z uwagi na to, że odpady komunalne są tzw. „paliwami mokrymi”. Koszt odparowania wilgoci z odpadów znacznie zmniejszał opłacalność stosowania tych paliw. Dopiero technologia skraplania spalin doprowadziła do przełomu w tej dziedzinie.

Ciepło powstające w procesie spalania odpadów mogłoby być wykorzystywane do produkcji energii elektrycznej, jednak ten proces musiałby być realizowany przy zastosowaniu kotłów wysokotemperaturowych. Wykorzystanie tych kotłów jest utrudnione z powodu konieczności użycia drogich i odpornych na korozję materiałów konstrukcyjnych, ponieważ w procesie wysokotemperaturowym korozyjne oddziaływanie spalin intensyfikuje się. Dlatego też w tym procesie uzyskanie efektywności elektrycznej wyższej niż 25\% stało się niemożliwe. Wtedy po raz pierwszy wprowadzono wariant tzw. „kogeneracji”, czyli połączonego pozyskiwania ciepła i energii elektrycznej. W procesach kogeneracji sprawność elektryczna obniża się o ok. 5\% przy jednoczesnym odzysku $80 \%$ ciepła odpadowego. Zastosowana technologia skraplania spalin dodatkowo ogranicza tzw. „straty kominowe”, tak więc w praktyce umożliwia odzysk energii, która zwykle tracona jest w kominie. W technologii tej następuje odzysk energii cieplnej, pobranej z kotła w celu osuszenia mokrych odpadów. Dzięki temu możliwe jest 
odzyskanie dodatkowo ponad 35\% energii cieplnej (Neterowicz 2009: 68-69).

Dzięki wykorzystanym technologiom efekt energetyczny ze spalania odpadów komunalnych określa się wg ciepła spalania odpadów suchych, czyli na poziomie $15 \mathrm{GJ} / \mathrm{kg}$, a nie tak jak zwykle wg wartości opałowej odpadów mokrych, na poziomie ok. $8 \mathrm{GJ} / \mathrm{kg}$ (Neterowicz 2009: 68-69).

Strukturę zużycia paliwa dla sieci ciepłowniczej w Szwecji prezentuje diagram przedstawiony na rys. 11 .

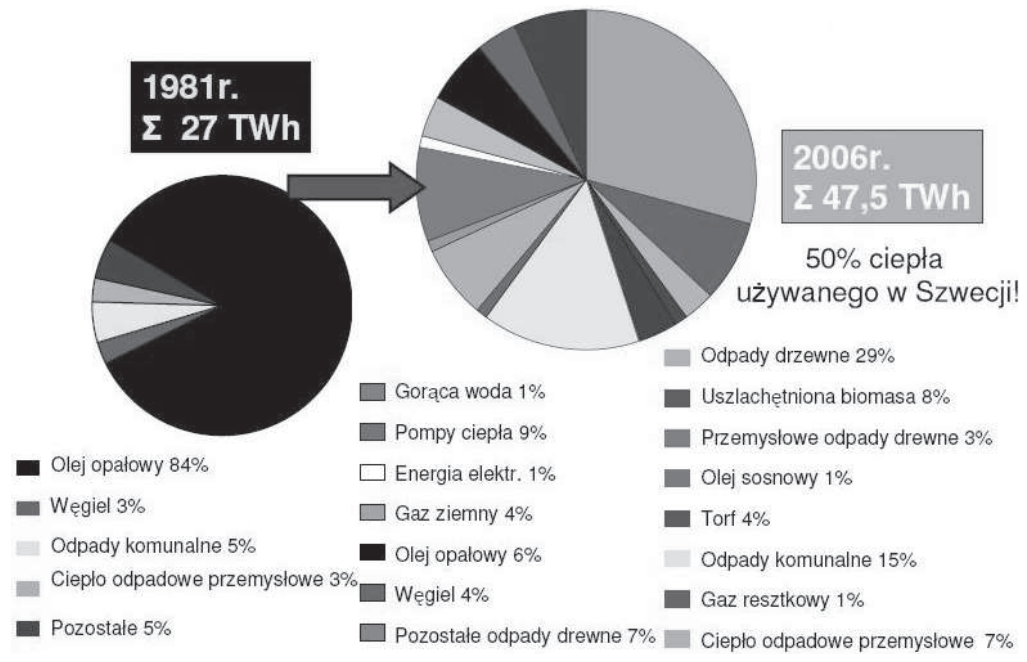

Rys. 11. Struktura zużycia paliwa dla sieci ciepłowniczej w Szwecji (porównanie roku bazowego 1981 i roku 2006) (Haglund 2010: 8)

Z rysunku nr 11 wynika, że w 1981 roku wśród paliw przeznaczonych do sieci ciepłowniczej zdecydowanie dominował olej opałowy. Ciepło z odpadów komunalnych stanowiło wówczas jedynie 5\%, a odpadowe ciepło przemysłowe jedynie 3\%. Natomiast w roku 2006 nastąpiła duża różnorodność paliw, na których czele stoją odpady drzewne w ilości około $29 \%$ uzyskiwanego z nich ciepła w sieci, wraz z odpadami komunalnymi w ilości 15\%. Ciepło odpadowe wykorzystywane jest w ilości 7\%, natomiast wykorzystanie konwencjonalnych źródeł ener- 
gii, takich jak olej opałowy, spadło do 6\%. W chwili obecnej ciepło odpadowe stanowi już około $10 \%$ ciepła w sieci. Przykładowo w mieście Borlänge $70 \%$ ciepła w sieci ciepłowniczej to ciepło odpadowe z papierni Kvarnsveden i huty stali SSAB/Domnarvet.

W Szwecji na początku roku 2010 istniały 24 spalarnie, zlokalizowane m.in. w Sztokholmie, Uppsali, Malmo, Göteborgu. Instalacje te utylizowały $45 \%$ odpadów, wykorzystywanych do wytwarzania energii ze źródeł odnawialnych. W chwili obecnej jest już 30 takich instalacji.

Już w roku 2004 w Szwecji tylko 9\% odpadów było składowanych na wysypiskach, natomiast aż $47 \%$ poddawano procesom spalania $\mathrm{z}$ odzyskiem energii, a około $44 \%$ poddawano procesom recyklingu. Natomiast w roku 2008 ilość składowanych odpadów spadła do 3\%, natomiast około $49 \%$ odpadów poddawano procesom spalania z odzyskiem energii, $35 \%$ poddawano procesom recyklingu, a około $13 \%$ ulegało procesom kompostowania.

Dobrym przykładem stosowania procesów WtE jest elektrociepłownia EC Högdalen w Sztokholmie. Instalacja ta jest największą w Europie spalarnią odpadów komunalnych, która przetwarza 750 tys. Mg odpadów rocznie. Instalacja ta położona jest na terenie parku narodowego w odległości zaledwie 12 kilometrów od centrum miasta. Obiekt ten powstał w latach $70 \mathrm{i}$ był stopniowo rozbudowywany. Aktualnie w czterech piecach rusztowych spalane są odpady komunalne (ponad 500 tys. ton) i przemysłowe (ponad 200 tys. ton) ze Sztokholmu oraz Norwegii i Finlandii. Spalarnia produkuje $450 \mathrm{GWh}$ energii elektrycznej i $1700 \mathrm{GWh}$ ciepła. Właścicielami zakładu są firma Fortum oraz miasto Sztokholm (Web-03).

Dopuszczalny okres składowania odpadów w bunkrze, do którego samochody zrzucają śmieci, wynosi dobę. To jedyne miejsce, gdzie możliwe jest odczuwanie nieprzyjemnego zapachu, jednak zasysanie powietrza wewnątrz bunkra eliminuje wydostawanie się odorów na zewnątrz. Wozy dostawcze są kontrolowane przez pracowników spalarni pod kątem toksyczności przywiezionych odpadów. Następnie z bunkra odpady przekazywane są do kotła, gdzie w temperaturze $1000^{\circ} \mathrm{C}$ są suszone, a następnie spalane. 
Zanieczyszczenia, które wydzielane są w procesie spalania zostają zneutralizowane dzięki najnowocześniejszym technologiom. Spaliny oczyszczane są najpierw w filtrze elektromagnetycznym, a następnie w filtrze chemicznym. Rtęć i dioksyny wychwytywane są w filtrach workowych, pokrytych węglem aktywnym. W kominie zamontowane są urządzenia monitorujące, a wielkość emisji można śledzić na wielkiej tablicy w dyspozytorni.

Z kolei instalacja EC Vattenfall przetwarza rocznie 355 tys. Mg odpadów komunalnych oraz $\mathrm{w}$ drugiej części obiektu mieszankę torfu i drewna. Z uwagi na wysoką opłacalność spalania, odpady sprowadzane są nie tylko z przyległych gmin, ale również z zagranicy z Norwegii i Finlandii. Rocznie instalacja ta produkuje 1700 GWh energii cieplnej oraz 250-350 GWh energii elektrycznej. Podobnie jak w Högdalen emisja zanieczyszczeń jest znacznie niższa niż rygorystyczne normy europejskie np. emisja dioksyn wynosi 0,001-0,04 ng/m $\mathrm{m}^{3}$ przy normie $0,1 \mathrm{ng} / \mathrm{m}^{3}$ (Web-03).

Przedstawiciele obu zakładów podkreślają korzyści ekonomiczne, wynikające z termicznej utylizacji odpadów. Przy wyśrubowanych normach i stałej kontroli obiekty są bezpieczne dla środowiska naturalnego oraz ludzi. Instalacje te są również wykonane z solidnych materiałów, np. w spalarni Högdalen nie było awarii od kilkunastu lat.

$\mathrm{Z}$ istniejących instalacji WtE w Szwecji uzyskuje się około 15\% krajowej energii. Tylko w roku 2008 w Szwecji wyprodukowano 4731660 $\mathrm{Mg}$ odpadów komunalnych pochodzących z gospodarstw domowych. Z tego wynika, że każdy obywatel szwedzki produkuje $511 \mathrm{~kg}$ odpadów na rok. Z ilości wszystkich rocznie produkowanych odpadów w Szwecji 3\% jest składowane (140 $250 \mathrm{Mg}$ ), 97\% poddawane jest procesom odzysku, a 1\% są to odpady niebezpieczne (43 $320 \mathrm{Mg})$. Około 35\% odpadów poddawanych jest recyklingowi (1 $657840 \mathrm{Mg}$ ) - są to różnego rodzaju opakowania (metal, szkło, tworzywa sztuczne, papier), makulatura, metal, a także odpady elektroniczne. Odpady organiczne poddawane obróbce biologicznej stanowią około 12,5\% (597 $280 \mathrm{Mg}$ ), a 48,5\% odpadów jest poddawanych procesom spalania z odzyskiem energii (2 292970 Mg). Ostatecznie w Szwecji oddaje się na składowi- 
sko odpadów jedynie 20 kg odpadów rocznie, w przeliczeniu na jednego mieszkańca (Haglund 2010, 15).

Odpady, które pozostają po segregacji u źródła i nie są oddawane do stacji recyklingu, poddawane są procesom spalania lub obróbce biologicznej. Dlatego też stosuje się system dwóch pojemników na odpady: $\mathrm{w}$ jednym $\mathrm{z}$ nich zbiera się odpady żywnościowe, które można poddać procesom obróbki biologicznej, w drugim natomiast zbiera się resztę odpadów przeznaczonych do spalenia. Już około 50\% szwedzkich gmin wprowadziła system zbierania odpadów organicznych, natomiast $30 \%$ planuje wprowadzenie takiego systemu.

Jeszcze jednym przykładem instalacji WtE w Szwecji, o którym należałoby wspomnieć jest instalacja w Gärstad. Skupia ona 50-letnie doświadczenie związane $\mathrm{z}$ WtE $\mathrm{w}$ jednej $\mathrm{z}$ najlepszych instalacji w Europie. Do spalarni tej zwożone są odpady od 600000 mieszkańców Szwecji, a całkowita moc przerobowa instalacji wynosi $420000 \mathrm{Mg}$ odpadów stałych w skali roku. W wyniku pracy instalacji o mocy 68 MW wytwarzana jest energia elektryczna w ilości 200 GWh oraz energia cieplna w ilości 1000 GWh w skali roku (Jacobsson et al. 21-25).

\section{Wnioski}

Wraz ze wzrostem poziomu konsumpcji, radykalnie wzrastają ilości wytwarzanych odpadów. Jak już wspomniano, jednym z głównych źródeł strumienia odpadów są odpady opakowaniowe. Technologie wytwarzania opakowań powodują także emisję gazów cieplarnianych oraz wymagają dostarczania energii. Problemy wytwarzania dużych ilości odpadów dotyczą najbardziej krajów bogatych, o wysokim i rosnącym poziomie konsumpcji. Stąd też koniecznym staje się wdrażanie technologii kompensujących straty energetyczne związane z procesami wytwarzania odpadów, a także zmniejszające zapotrzebowanie na konwencjonalne nośniki energii takie jak ropa naftowa, gaz ziemny czy też węgiel.

W programach badawczych i dokumentach Unii Europejskiej wprowadzono pojęcie „paliw alternatywnych”, wytwarzanych z miedzy innymi surowców odpadowych pochodzenia bytowego i przemysłowego, 
spełniających wymagania środków transportu lub urządzeń cieplnych i elektroenergetycznych.

W zakresie paliw do celów transportowych, do biopaliw zaliczono także paliwa płynne pochodzące $\mathrm{z}$ odpadowej biomasy czy też z części biodegradowalnej odpadów komunalnych (procesy WtL - waste to liquid). Jednak $\mathrm{w}$ zastosowaniach stacjonarnych to procesy WtE, realizowane $\mathrm{w}$ procesach kogeneracji (ciepło i energia elektryczna) w systemach CHP (combined heat and power) oraz poligeneracji (ciepło-chłód-energia elektryczna) nabierają coraz to większego znaczenia. Na etapie wdrażania znajdują się technologie wykorzystywania różnego pochodzenia substancji odpadowych, nie tylko komunalnego, służące nawet do wytwarzania paliw do silników lotniczych, jak na przykład technologia Solena Group wdrażana przez British Airways. Zważywszy więc na postęp technologiczny umożliwiający przetwarzanie odpadów do wysokojakościowych nośników energii nawet do zastosowań w lotnictwie, konieczne staje się radykalne zwiększenie wykorzystywania odpadów w procesach WtE, czego przykładem są przedstawione miedzy innymi doświadczenia szwedzkie i holenderskie. Uwzględniając efektywność procesów WtE w zakresie kryteriów energetycznych, ekonomicznych oraz socjalnych, przy wzroście podaży potencjalnego surowca jakim są odpady, należy dążyć do coraz intensywniejszego wdrażania tych procesów. Problem ten dotyczy szczególnie Polski, która jest jednym z krajów europejskich o największych ilościach składowanych odpadów. W procesach WtE, niezależnie od możliwości uzyskania dodatkowych źródeł energii, na podkreślenie zasługuje fakt istotnego zmniejszania emisji GHG w tych procesach, w przeliczeniu na ekwiwalent ditlenku węgla.

Zwiększanie efektywności procesów WtE wymaga znacznego podwyższenia świadomości społeczeństwa w zakresie ochrony środowiska, ponieważ w wielu przypadkach, szczególne w Polsce, niczym nie uzasadniony tak zwany „strach ekologiczny”, uniemożliwia budowanie instalacji dla technologii WtE. Stąd też procesy edukacyjne w tym zakresie powinny być prowadzone od najniższego szczebla edukacji, ponieważ odpowiednio wyedukowana młodzież może wpływać pozy- 
tywnie na poziom świadomości rodziców, co ma szczególne znaczenie w środowiskach wiejski i małych miastach i miejscowościach.

Doświadczenia w zakresie procesów WtE, wykazane powyżej, powinny być zatem wykorzystane $\mathrm{w}$ racjonalizacji gospodarki odpadami w Polsce. Proces ten zapewne wymagał będzie, niezależnie od konieczności radykalnych zmian w świadomości społecznej, korekty lub zmiany określonych przepisów w zakresie gospodarki odpadami, w tym uwarunkowań fiskalnych.

\section{Bibliografia}

Czajka K., Mokrzycki E., Uliasz-Bocheńczyk A., marzec 2000, Zasoby energetyczne odpadów, materiały z II Sympozjum „Energia z odpadów”, Sopot.

Themelis N. J., 2003, An overview of the global waste-to-energy industry, Waste Management World, 2003-2004 Review Issue, s. 40-47;

Brochure of Confederation of European Waste-to-Energy Plants "CEWEP", 2009, Waste in (mega) watt out, (www.cewep.eu).

Renewable Energy in the U.S. - Waste to Energy, 2008, Swedish Trade Council, USA.

Spohn C., 24.01.2010, Waste-to-Energy - Solutions, Technologies, Examples, Waste-toEnergy Conference, Malta.

Spohn C., 2010, Potential drivers and current barriers of Waste-to-Energy.

Den Herder K., 13.04.2007, Ministry of Housing, Spatial planning and the Environment. Waste to Energy: Dutch policy \& international perspective. Visit of delegation of Polish experts, Haga, slajdy: 3-20.

Neterowicz J., 19-22.10.2009, Rozwój systemów gospodarki odpadami i spalarni odpadów w Szwecji, Materiały z VI Międzynarodowej Konferencji „Termiczne przekształcanie odpadów - od planów do realizacji”, Szczecin - Kopenhaga, str. 68-69

Haglund G., 28.01.2010, Waste-to-Energy!, Materiały z Międzynarodowej konferencji „Najnowsze wymiary polityki klimatycznej - Trzy idee, które czynią wolnym”, Warszawa, slajdy: 8-31.

Jacobsson S., Elez M., Berggren E., Waste to Energy - The Swedish experience - or how to turn a problem into asset, Swedish Waste to Energy Solutions USITALL, paper.

\section{Witryny internetowe}

(Web-01) <http://blog.cleantechies.com/2009/08/14/waste-to-energy-what-can-we-learn-from-the-dutch/>, dostęp: 03.2010.

(Web-02) <http://www.aebamsterdam.com/en/What-we-do.aspx>, dostęp: 09.2010.

(Web-03) <http://www.spalarnia.krakow.pl/SzwedzkieWzoryDlaKrakowskiej.html>, dostęp: 11.2010 . 


\section{SUMMARY}

This article present waste management in the world and in some highly developed countries in the European Union such as Germany, Netherlands and Sweden. Article presented also waste management systems in these countries, with special attention to the processes of energy use of waste (Waste to Energy - WTE) in existing plants. 